\title{
Comparative toxicity of essential oil and blends of selected terpenes of Ocotea species from Pernambuco, Brazil, against Tetranychus urticae Koch
}

\author{
MARCILIO M. DE MORAES, CLAUDIO A.G. DA CAMARA and MILENA M.C. DA SILVA
}

Programa de Pós-Graduação em Química, Laboratório de Produtos Naturais Bioativos, Universidade Federal Rural de Pernambuco, Departamento de Química, Av. Dom Manoel de Medeiros, s/n, 52171-900 Recife, PE, Brazil

Manuscript received on February 22, 2017; accepted for publication on March 31, 2017

\begin{abstract}
Essential oils from the leaves of two species of the genus Ocotea that occur in the Atlantic Forest in the state of Pernambuco, Brazil, were analyzed using gas chromatography-mass spectrometry. The acaricidal activity of these oils as well as 11 selected components and blends were evaluated in fumigation and residual contact tests against the two-spotted spider mite (Tetranychus urticae). Sixty-seven constituents were identified, totaling $97.3 \pm 0.3 \%$ and $97.8 \pm 0.5 \%$ of the oils from $O$. duckei and $O$. glomerata, respectively. Sesquiterpene was the dominant class. The compounds $\beta$-caryophyllene $(18.6 \pm 0.1 \%)$ and aromadendrene $(17.3 \pm 0.6 \%)$ were the main constituents of the oils from $O$. duckei and O. glomerata, respectively. Acaricidal action varied depending on the method employed, species and chemical nature of the selected constituents. The mites were susceptible to the oils and chemical constituents using the fumigation method. The $O$. duckei oil was respectively 2.5 -fold and 1.5 -fold more toxic than the $O$. glomerata oil using the fumigation and residual contact methods. Among the selected constituents, $\beta$-caryophyllene was the most toxic, independently of the method employed. The individual toxicity of the selected compounds and their blends as well as the role of these constituents in the overall toxicity of the essential oils are also discussed.
\end{abstract}

Key words: acaricidal activity, $\beta$-caryophyllene, essential oil, Ocotea, Tetranychus urticae.

\section{INTRODUCTION}

Ocotea is one of the most representative genera of the family Lauraceae, with approximately 400 species of plants distributed throughout the American and African continents (van der Werff 1991). It is estimated that between 120 and 160 of the species for this genus occur in Brazil (Baitello 2001), with 52 species recorded for the northeastern region of the country (Quinet et al. 2010) and 11

Correspondence to: Claudio Augusto Gomes da Camara

E-mail: claudio_agc@hotmail.com recorded for the state of Pernambuco within this region (Barreto 1990).

Species of the genus produce a large amount of essential oils and these plants are widely used in civil construction, furniture manufacturing and cooking practices (Moraes 2005). Due to the economic potential, uncontrolled extractivism has led to the decline of natural populations, placing some species at risk of extinction, such as Ocotea catharinensis Mez, Ocotea langsdorffii (Meisn.) Mez and Ocotea porosa (Nees \& C. Mart.) Barroso (IBAMA 1992). Plants from the genus Ocotea are 
also used in folk medicine for the treatment of infections, headaches, ulcers, menstrual cramps, snake bites, diarrhea, neuralgia, indigestion and pain in general (Coutinho et al. 2006, Moraes 2005, Morais 1998).

There are several reports in the literature on the chemical composition of oils from species of Ocotea that occur in various regions of the world. These oils are extracted from different parts of the plant and the main chemical classes found are monoterpenes (Olivero-Verbel et al. 2010), sesquiterpenes, diterpenes (Setzer et al. 2006, Takaku et al. 2007, Yamaguchi et al. 2013) and phenylpropanoids (Oltramari et al. 2004). Studies on the biological properties of these essential oils reveal a broad spectrum of activity, including antimicrobial (Leporatti et al. 2014, Farago et al. 2010), anti-inflammatory, cytotoxic, antioxidant (Destryana et al. 2014, Chaverri et al. 2011) and molluscicidal (Coutinho et al. 2007) properties, including insecticidal action against arthropods of medicinal interest, such as Aedes aegypti (Menut et al. 2002), and agricultural interest, such as Sitophilus zeamais (Mossi et al. 2013). To date, however, no studies have addressed the acaricidal activity of these oils.

The two-spotted spider mite (Tetranychus urticae Koch) is a major agricultural pest throughout the world. In Brazil, this polyphagous, cosmopolitan pest has caused serious damage to bean, tomato and papaya crops as well as ornamental plants grown in the field and in green houses.

The use of natural products for the control of agricultural pests has intensified in recent years (da Camara et al. 2015, Isman and Miresmailli 2011, Isman et al. 2011). Our research group has recently conducted investigations of substances with acaricidal properties as alternatives to conventional pesticides for use in the integrated management of T. urticae (Ribeiro et al. 2016, Nascimento et al. 2012, Neves and da Camara 2011). Moreover, few studies are found in the literature on the acaricidal activity of the chemical constituents of essential oils and their role in the biological activity of such oils. Using the acaricidal action of individual chemical constituents, it is possible to prepare artificial blends through the selection of the best combination of compounds for use in the integrated management of the two-spotted spider mite as well as investigate the degree of contribution of each compound in the artificial oil (Neves and da Camara 2016, Moraes et al. 2012, Jiang et al. 2009, Miresmailli et al. 2006)

Ocotea duckei Vattimo-Gil and Ocotea glomerata (Nees) Mez are among the species that occur in remaining fragments of the Atlantic Forest in the state of Pernambuco (northeastern Brazil). These species are locally known as louro pimenta and caneleira, respectively. A bibliographic survey revealed that no previous studies have investigated the chemical and biological properties of the essential oil from O. glomerata. Moreover, although there are reports of the chemical characterization and cardiovascular effect of the essential oil from O. duckei (Barbosa-Filho et al. 2007), which occurs in the state of Paraíba (northeastern Brazil), the literature offers no studies on the acaricidal activity of this oil against Tetranychus uticae.

Therefore, as part of systematic research on the aromatic flora and acaricidal activity of plants from northeastern Brazil, the focus of the present study was on the chemical composition and acaricidal activity against $T$. urticae of essential oils from $O$. duckei and O. glomerata that grow wild in fragments of the Atlantic Forest. The relationship between the toxicity of the selected constituents and their blends was also investigated.

\section{MATERIALS AND METHODS}

\section{COLLECTION OF PLANT MATERIAL}

Fresh leaves from Ocotea duckei and Ocotea glomerata were collected in the Mata Senhorzinho Cabral, in Camocim de São Félix in September 
2010. The geographical coordinates of the collection point was $07^{\circ} 58^{\prime} 41.2^{\prime \prime} \mathrm{S} 034^{\circ} 50^{\prime} 21.4^{\prime \prime} \mathrm{W}$. The plants were identified by botanist Dr. Maria R. C. S. de Melo (University Federal Rural of Pernambuco). Vouchers of both samples were mounted and deposited in the Vasconcelos Sobrinho Herbarium of the UFRPE under numbers 19951 Ocotea duckei and 49645 Ocotea glomerata.

\section{OPTICAL ROTATION}

Optical rotation of the essential oils was performed with a digital polarimeter (A. Krüss model Px800, Germany) at $589 \mathrm{~nm}$ and $25^{\circ} \mathrm{C}$ in a dichloromethane solution.

\section{CHEMICALS}

All monoterpenes ( $\alpha$-pinene, $\beta$-pinene, $p$-cymene, limonene, terpinolene, terpinen-4-ol and $\alpha$-terpineol), sesquiterpenes ( $\beta$-caryophyllene, aromadendrene, $\alpha$-humulene and valencene) and eugenol used as control positive for fumigant test were purchased from Sigma-Aldrich, Brazil. Azamax used as a positive control in the residual contact test was acquired from the local market in Recife, Pernambuco, Brazil.

\section{ESSENTIAL OIL EXTRACTION AND GAS \\ CHROMATOGRAPHY FID ANALYSIS}

The essential oils from the fresh leaves (100 g) of Ocotea species were obtained by hydrodistillation using a modified Clevenger apparatus for $4 \mathrm{~h}$. The oil layers were separated and dried over anhydrous sodium sulfate, stored in hermetically sealed glass containers, and kept at a low temperature $\left(-5^{\circ} \mathrm{C}\right)$ until the acaricidal assays and analysis. Total oil yields were expressed as percentages $(\mathrm{g} / 100 \mathrm{~g}$ of fresh plant material). All experiments were carried out in triplicate. GC identification was carried out using a Hewlett-Packard 5890 Series II GC apparatus equipped with a flame ionization detector (FID) and a non-polar DB-5 fused silica capillary column
(30 m x $0.25 \mathrm{~mm} \times 0.25 \mu \mathrm{m}$ film thickness) (J \& W Scientific). The oven temperature was programmed from 60 to $240^{\circ} \mathrm{C}$ at a rate $3^{\circ} \mathrm{C} \mathrm{min}^{-1}$. Injector and detector temperatures were $260^{\circ} \mathrm{C}$. Hydrogen was used as the carrier gas at a flow rate of $1 \mathrm{~mL} \mathrm{~min}^{-1}$ in split mode (1:30). The injection volume was $0.5 \mu \mathrm{L}$ of diluted solution (1/100) of oil in $n$-hexane. The percentage of each compound was obtained from GC-FID peak areas in the order of the DB-5 column elution and expressed as the relative percentage of the area of the chromatograms. Analysis was conducted in triplicate.

\section{GAS CHROMATOGRAPHY-MASS SPECTROMETRY ANALYSIS}

The GC-MS analysis of the essential oils was carried out using a Varian 220-MS IT GC system with a mass selective detector, mass spectrometer in EI $70 \mathrm{eV}$ with a scan interval of $0.5 \mathrm{~s}$ and fragments from 40 to $550 \mathrm{Da}$. fitted with the same column and temperature program as that for the GC-FID experiments, with the following parameters: carrier gas $=$ helium; flow rate $=1 \mathrm{~mL} \mathrm{~min}^{-1}$; split mode (1:30); injected volume $=1 \mu \mathrm{L}$ of diluted solution $(1 / 100)$ of oil in $n$-hexane.

\section{IDENTIFICATION OF COMPONENTS}

Identification of the components was based on GC-MS retention indices with reference to a homologous series of $\mathrm{C}_{8}-\mathrm{C}_{40} \mathrm{n}$-alkanes calculated using the van Den Dool and Kratz equation (van Den Dool and Kratz 1963) and by computer matching against the mass spectral library of the GC-MS data system (NIST version 14 and WILEY version 11) and co-injection with authentic standards as well as other published mass spectra (Adams 2007). Area percentages were obtained from the GC-FID response without the use of an internal standard or correction factors. 


\section{ACARICIDAL ASSAY}

Specimens of T. urticae used for the bioassays were reared on jack beans (Canavalia ensiformes L.) without any exposure to acaricidal agents at the Agronomy Department of the Rural Federal University of Pernambuco, Brazil. All bioassays were performed at a temperature of $25 \pm 1{ }^{\circ} \mathrm{C}$, with relative humidity of $65 \pm 5 \%$ and a 12 -h photoperiod.

FUMIGATION AND RESIDUAL CONTACT BIOASSAYS OF OILS, SELECTED COMPOUNDS AND ARTIFICIAL OILS

The fumigation and residual contact methods were the same as those employed by Araújo et al. (2012). The mortality data for the Ocotea oils, selected compounds and blends were analyzed using the probit model with the aid of the POLO-PC software program (LeOra 1987) for the determination of the lethal concentration necessary for $50 \%$ mortality $\left(\mathrm{LC}_{50}\right)$ of the mite population, with the calculation of $95 \%$ confidence levels. Toxicity ratios were determined based on the method described by Robertson and Preisler (1992). The data were submitted to analysis of variance (ANOVA) and means were compared using Tukey's test, with the level of significance set to $5 \%(p<0.05)$. In the fumigation bioassays, the concentrations ranged from 0.08 to $3.6 \mu \mathrm{L} \mathrm{L}^{-1}$ of air for the oils, $3.2 \times 10^{-4}$ to $26 \mu \mathrm{L} \mathrm{L}^{-1}$ of air for the selected compounds and 0.15 to $4.5 \mu \mathrm{L} \mathrm{L}^{-1}$ of air for the blends. In the residual contact bioassays, concentrations ranged from 0.10 to $15.0 \mu \mathrm{L} \mathrm{mL}^{-1}$ for the oils, 0.1 to $675.0 \mu \mathrm{L} \mathrm{mL}^{-1}$ for the selected compounds and 0.10 to $40.5 \mu \mathrm{L} \mathrm{L}^{-1}$ of air for the blends. The results were submitted to descriptive analysis using the Statistical Analysis System program (SAS 2002). The artificial oils were prepared with selected compounds from the $O$. duckei and $O$. glomerata oils at the same proportions as those identified by gas chromatography-mass spectrometry (GC-MS) and gas chromatography with a flame ionization detector (GC-FID), as shown in Table III.

\section{COMPARATIVE TOXICITY OF INCOMPLETE BLENDS}

Incomplete blends were prepared from artificial oil to investigate the relationship between the compounds selected from the essential oils of Ocotea and their toxicity, with each blend lacking one constituent. The respective fumigation and residual contact activities were evaluated. The toxicity of the incomplete blends was evaluated at the same concentration as that of the Ocotea oils that promoted $\geq 96.0 \%$ mortality in the fumigation bioassays: 12 and $20 \mu \mathrm{L} \mathrm{L}^{-1}$ of air for the essential oil from $O$. duckei and $O$. glomerata, respectively; in residual contact bioassays: 46 and $31 \mu \mathrm{L} \mathrm{mL}^{-1}$ for the essential oil from $O$. duckei and O. glomerata, respectively.

\section{RESULTS AND DISCUSSION}

\section{CHEMICAL COMPOSITION OF Ocotea OILS}

The oils obtained through hydrodistillation exhibited a light yellow color and citric aroma. No significant differences were found between the yields of oil from the fresh leaves of the two species. Table I displays the yields, specific rotations and compounds identified in the leaf oils from Ocotea duckei and O. glomerata. In the comparison of the findings with data from the literature, the yield of the oil from $O$. duckei in the present study (1.6 \pm $0.0 \%$ ) was higher than that reported by BarbosaFilho et al. (2007) for leaves of a specimen collected in the state of Paraíba (0.7\%). The specific rotation values for the Ocotea oils were levorotary, with large angles for the O. glomerata oil and small angles for the $O$. duckei oil.

The GC-MS analysis of the essential oils revealed a total of 67 compounds, corresponding to $97.3 \pm 0.3 \%$ and $97.8 \pm 0.5 \%$ of the chemical 
TABLE I

Percentage composition, yield and optical rotation of essential oils from $O$. duckei and $O$. glomerata.

\begin{tabular}{|c|c|c|c|c|c|}
\hline $\begin{array}{c}\text { Compound } \\
\text { Yield }(\%) \pm \text { sd } \\
{[\alpha]_{\mathrm{D}}^{25}\left(\mathrm{c} .=1, \mathrm{CH}_{2} \mathrm{Cl}_{2}\right)}\end{array}$ & $\mathrm{RI}^{\mathrm{a}}$ & $\mathrm{RI}^{\mathrm{b}}$ & $\begin{array}{c}\text { O. duckei } \\
1.6 \pm 0.0 \\
-8.9^{\circ} \\
\end{array}$ & $\begin{array}{c}\text { O. glomerata } \\
1.8 \pm 0.1 \\
-19.1^{\circ} \\
\end{array}$ & $\begin{array}{l}\text { Method of } \\
\text { identification }\end{array}$ \\
\hline artemisia triene & 920 & 923 & - & $0.6 \pm 0.0$ & RI, MS \\
\hline$\alpha$-pinene & 928 & 932 & $2.5 \pm 0.1$ & $6.9 \pm 0.1$ & RI, MS,CI \\
\hline verbenene & 957 & 961 & $0.3 \pm 0.0$ & - & RI, MS \\
\hline sabinene & 965 & 969 & $0.3 \pm 0.0$ & - & RI, MS \\
\hline$\beta$-pinene & 970 & 974 & $5.2 \pm 0.0$ & - & RI, MS, CI \\
\hline myrcene & 985 & 988 & $5.6 \pm 0.0$ & - & RI, MS \\
\hline$\alpha$-phellandrene & 999 & 1002 & - & $0.4 \pm 0.0$ & RI, MS \\
\hline iso-sylvestrene & 1006 & 1008 & - & $1.1 \pm 0.0$ & RI, MS \\
\hline$p$-cymene & 1017 & 1020 & - & $4.9 \pm 0.0$ & $\mathrm{RI}, \mathrm{MS}, \mathrm{CI}$ \\
\hline limonene & 1024 & 1024 & $1.1 \pm 0.0$ & $1.0 \pm 0.0$ & RI, MS, CI \\
\hline$\gamma$-terpinene & 1050 & 1054 & $0.7 \pm 0.0$ & $6.4 \pm 0.0$ & RI, MS \\
\hline$m$-cymene & 1081 & 1082 & $0.7 \pm 0.0$ & - & RI, MS \\
\hline terpinolene & 1084 & 1086 & - & $2.1 \pm 0.1$ & $\mathrm{RI}, \mathrm{MS}, \mathrm{CI}$ \\
\hline trans-pinene hydrate & 1119 & 1119 & $0.1 \pm 0.0$ & - & RI, MS \\
\hline terpinen-4-ol & 1168 & 1174 & - & $0.4 \pm 0.0$ & $\mathrm{RI}, \mathrm{MS}, \mathrm{CI}$ \\
\hline$\alpha$-terpineol & 1188 & 1186 & $0.3 \pm 0.0$ & - & $\mathrm{RI}, \mathrm{MS}, \mathrm{CI}$ \\
\hline iso-menthyl acetate & 1308 & 1304 & $2.0 \pm 0.0$ & - & RI, MS \\
\hline$\delta$-elemene & 1335 & 1335 & - & $0.3 \pm 0.0$ & RI, MS \\
\hline$\alpha$-cubebene & 1340 & 1345 & - & $1.2 \pm 0.0$ & RI, MS \\
\hline$\alpha$-terpinyl acetate & 1350 & 1346 & $1.4 \pm 0.0$ & - & RI, MS \\
\hline ylangene & 1370 & 1373 & - & $0.3 \pm 0.0$ & RI, MS \\
\hline$\alpha$-copaene & 1372 & 1374 & $1.2 \pm 0.0$ & - & RI, MS \\
\hline$\beta$-cubebene & 1388 & 1387 & $1.8 \pm 0.0$ & - & RI, MS \\
\hline$\beta$-bourbonene & 1390 & 1387 & $0.1 \pm 0.0$ & $3.1 \pm 0.0$ & RI, MS \\
\hline$\beta$-elemene & 1384 & 1389 & - & $0.3 \pm 0.0$ & RI, MS \\
\hline$\beta$-caryophyllene & 1415 & 1417 & $18.1 \pm 0.1$ & $14.6 \pm 0.3$ & RI, MS, CI \\
\hline$\beta$-duprezianene & 1418 & 1421 & - & $0.6 \pm 0.0$ & RI, MS \\
\hline$\beta$-copaene & 1428 & 1430 & - & $0.3 \pm 0.0$ & RI, MS \\
\hline$\beta$-gurjunene & 1431 & 1431 & - & $0.5 \pm 0.0$ & RI, MS \\
\hline aromadendrene & 1437 & 1439 & $0.5 \pm 0.0$ & $17.3 \pm 0.6$ & $\mathrm{RI}, \mathrm{MS}, \mathrm{CI}$ \\
\hline prezizaene & 1443 & 1444 & - & $1.9 \pm 0.0$ & RI, MS \\
\hline$\alpha$-humulene & 1455 & 1452 & $2.2 \pm 0.0$ & - & RI, MS, CI \\
\hline dehydro-aromadendrene & 1457 & 1460 & $3.0 \pm 0.0$ & - & RI, MS \\
\hline cumacrene & 1466 & 1470 & $4.7 \pm 0.1$ & - & RI, MS \\
\hline germacrene D & 1480 & 1484 & - & $2.1 \pm 0.0$ & RI, MS \\
\hline$\beta$-selinene & 1483 & 1489 & - & $2.3 \pm 0.1$ & RI, MS \\
\hline$\delta$-selinene & 1489 & 1492 & $1.5 \pm 0.0$ & - & RI, MS \\
\hline
\end{tabular}


TABLE I (continuation)

\begin{tabular}{|c|c|c|c|c|c|}
\hline $\begin{array}{c}\text { Compound } \\
\text { Yield }(\%) \pm \text { sd } \\
{[\alpha]_{\mathrm{D}}^{25}\left(\mathrm{c} .=1, \mathrm{CH}_{2} \mathrm{Cl}_{2}\right)} \\
\end{array}$ & $\mathrm{RI}^{\mathrm{a}}$ & $\mathrm{RI}^{\mathrm{b}}$ & $\begin{array}{c}\text { O. duckei } \\
1.6 \pm 0.0 \\
-8.9^{\circ} \\
\end{array}$ & $\begin{array}{c}\text { O. glomerata } \\
1.8 \pm 0.1 \\
-19.1^{\circ} \\
\end{array}$ & $\begin{array}{c}\text { Method of } \\
\text { identification }\end{array}$ \\
\hline$\gamma$-amorphene & 1490 & 1495 & - & $1.6 \pm 0.0$ & RI, MS \\
\hline valencene & 1496 & 1496 & $17.6 \pm 0.0$ & - & RI, MS, CI \\
\hline$\alpha$-muurolene & 1501 & 1500 & $1.9 \pm 0.0$ & $2.1 \pm 0.0$ & RI, MS \\
\hline bicyclogermacrene & 1504 & 1500 & $2.7 \pm 0.0$ & $5.8 \pm 0.2$ & RI, MS \\
\hline$\beta$-bisabolene & 1507 & 1505 & $0.2 \pm 0.0$ & - & RI, MS \\
\hline$\delta$-amorphene & 1511 & 1511 & - & $1.1 \pm 0.0$ & RI, MS \\
\hline$\delta$-cadinene & 1520 & 1522 & $0.6 \pm 0.0$ & $0.6 \pm 0.0$ & RI, MS \\
\hline zonarene & 1525 & 1528 & - & $2.0 \pm 0.0$ & RI, MS \\
\hline$\alpha$-cadinene & 1535 & 1537 & - & $4.0 \pm 0.1$ & RI, MS \\
\hline$\alpha$-calacorene & 1545 & 1544 & - & $2.8 \pm 0.0$ & RI, MS \\
\hline elemol & 1550 & 1548 & $6.8 \pm 0.0$ & - & RI, MS \\
\hline trans-dauca-4(11),7-diene & 1557 & 1556 & $2.4 \pm 0.0$ & - & RI, MS \\
\hline maliol & 1562 & 1566 & - & $0.2 \pm 0.0$ & RI, MS \\
\hline longipinanol & 1563 & 1567 & - & $0.8 \pm 0.0$ & RI, MS \\
\hline palustrol & 1564 & 1567 & - & $0.4 \pm 0.0$ & RI, MS \\
\hline caryophyllene alcohol & 1568 & 1570 & - & $0.6 \pm 0.0$ & RI, MS \\
\hline$\alpha$-cedrene epoxide & 1572 & 1574 & $1.0 \pm 0.0$ & - & RI, MS \\
\hline spathulenol & 1574 & 1577 & $0.6 \pm 0.0$ & $3.6 \pm 0.1$ & RI, MS \\
\hline tujopsan-2- $\beta$-ol & 1586 & 1588 & $0.6 \pm 0.0$ & - & RI, MS \\
\hline globulol & 1590 & 1590 & $1.1 \pm 0.0$ & - & RI, MS \\
\hline viridiflorol & 1595 & 1592 & - & $2.8 \pm 0.0$ & RI, MS \\
\hline rosifoliol & 1603 & 1600 & - & $0.7 \pm 0.0$ & RI, MS \\
\hline ledol & 1607 & 1602 & $0.7 \pm 0.0$ & - & RI, MS \\
\hline trans-isolongifolane & 1626 & 1625 & - & $0.5 \pm 0.0$ & RI, MS \\
\hline$\alpha$-muurolol & 1642 & 1644 & $5.6 \pm 0.0$ & - & RI, MS \\
\hline cubenol & 1647 & 1645 & - & $1.3 \pm 0.0$ & RI, MS \\
\hline cadinol & 1649 & 1652 & $3.6 \pm 0.0$ & - & RI, MS \\
\hline$\beta$-eudesmol & 1649 & 1652 & $0.6 \pm 0.0$ & - & RI, MS \\
\hline elemol acetate & 1675 & 1680 & $0.9 \pm 0.0$ & - & RI, MS \\
\hline amorpha-4,9-dien-2-ol & 1703 & 1700 & $0.1 \pm 0.0$ & - & RI, MS \\
\hline sclareolide & 2060 & 2065 & $0.1 \pm 0.0$ & - & RI, MS \\
\hline Monoterpenes & & & $20.8 \pm 0.1$ & $25.0 \pm 0.1$ & \\
\hline Sesquiterpenes & & & $76.5 \pm 0.3$ & $72.8 \pm 0.7$ & \\
\hline Total & & & $97.3 \pm 0.3$ & $97.8 \pm 0.7$ & \\
\hline
\end{tabular}

${ }^{a}$ Retention indices calculated from retention times in relation to those of a series of n-alkanes on a $30 \mathrm{~m}$ DB-5 capillary column. ${ }^{\mathrm{b}}$ Linear retention indices from the literature. $\mathrm{RI}=$ retention index, $\mathrm{MS}=$ mass spectrum, $\mathrm{CI}=$ co-injection with authentic standards. 
composition of the $O$. duckei and $O$. glomerata oils, respectively. The oils exhibited a terpene chemical profile (monoterpenos and sesquiterpenes), with sesquiterpenes as the dominant class: $76.5 \pm 0.3 \%$ in the $O$. duckei oil and $72.8 \pm 0.7 \%$ in the $O$. glomerata oil. The predominance of sesquiterpenes in the oils of species of Ocotea that occur in the state of Pernambuco is in agreement with data reported for oils from other species of the genus that occur in various regions of the world (Ballabeni et al. 2007, Chaverri and Cicció 2007, Coutinho et al. 2007, Setzer et al. 2006, Takaku et al. 2007). With the exception of oils from the fruit and leaves of $O$. odorifera (Mossi et al. 2013, Oltramari et al. 2004) collected in the state of Rio Grande do Sul (southern Brazil) and the leaves of O. puchury-major (Leporatti et al. 2014) collected in the state of Amazonas (northern Brazil), in which phenylpropanoides are the predominant chemical class, the abundance of sesquiterpenes found in the oils in the present study is also in agreement with data reported for other species of the genus that occur in different regions of Brazil (Sacchetti et al. 2006, Coutinho et al. 2007, Farago et al. 2010, Garrett et al. 2010 Yamaguchi et al. 2013), including the northeastern region in a sample of $O$. duckei collected in the state of Paraíba (BarbosaFilho et al. 2007).

Among the 67 compounds identified in the oils analyzed herein, only ten were common to both $O$. duckei and $O$. glomerata. $\beta$-caryophyllene $(18.1 \pm 0.1 \%)$, valencene $(17.6 \pm 0.0 \%)$, $\beta$-pinene $(5.2 \pm 0.0 \%)$, myrcene $(5.6 \pm 0.0 \%)$, cumacrene $(4.7 \pm 0.1 \%)$, elemol $(6.8 \pm 0.0 \%)$ and $\alpha$-muurolol $(5.6 \pm 0.0 \%)$ were the major constituents in the $O$. duckei oil. Among these compounds, only $\beta$-caryophyllene was also found in the $O$. glomerata oil, suggesting considerable chemical diversity. The major constituents of the O. glomerata oil were aromadendrene (17.3 \pm $0.6 \%), \beta$-caryophyllene $(14.6 \pm 0.3 \%), \alpha$-pinene $(6.9 \pm 0.1 \%), p$-cymene $(4.9 \pm 0.0 \%), \gamma$-terpinene
$(6.4 \pm 0.0 \%)$, bicyclogermacrene $(5.8 \pm 0.2 \%)$ and $\alpha$-cadinene $(4.0 \pm 0.1 \%)$.

$\beta$-caryophyllene was also the major component in the essential oil from $O$. duckei leaves reported by Barbosa-Filho et al. (2007), corresponding to $60.54 \%$ of the oil. The authors identified eight compounds corresponding to $74.7 \%$ of the essential oil from $O$. duckei occurring in the state of Paraíba.

The present study shows that the chemical profile of the essential oil from $O$. duckei does not differ significantly based on location (states of Paraíba and Pernambuco). However, the chemical analysis of $O$. duckei and $O$. glomerata enables the inference of qualitative and quantitative differences between the essential oils. The chemical profile rich in monoterpenes and sesquiterpenes characterized in the oils from the species of Ocotea that occur in the state of Pernambuco is typical of essential oils from some species of Ocotea in South America (Chaverri et al. 2011).

\section{TOXICITY OF ESSENTIAL OILS AND SELECTED CHEMICAL CONSTITUENTS}

Table II displays the results of the fumigation and residual contact bioassays with the Ocotea oils. Acaricidal activity varied in accordance with the type of oil and method employed. The $O$. duckei oil was 2.5 -fold and 1.5 -fold more toxic than the $O$. glomerata oil in the fumigation and residual contact bioassays, respectively. Thus, the mites were more susceptible to the penetration of oil vapors in the airways (fumigation) than through the tarsi and/ or ingestion (residual contact). These results are in agreement with data on the toxicity of other oils on the same pest (Neves and da Camara 2016, Moraes et al. 2012). However, neither oil was more active than eugenol and azamax, which were used as the positive control in the fumigation and residual contact bioassays, respectively.

The differences in toxicity against $T$. urtice between the $O$. duckei and $O$. glomerata oils may be attributed to the qualitative and quantitative 
TABLE II

Fumigation toxicity $\left(\mathrm{LC}_{50}\right.$ at $\mu \mathrm{L} \mathrm{L}^{-1}$ of air) and residual contact $\left(\mathrm{LC}_{50}\right.$ at $\left.\mu \mathrm{L} \mathrm{mL} \mathrm{L}^{-1}\right)$ of the blends of selected constituents and essential oils of $O$. duckei and $O$. glomerata.

\begin{tabular}{|c|c|c|c|c|c|c|c|}
\hline Oil/blends & Bioassay & $\mathbf{n}$ & df & slope & $\begin{array}{c}\text { Fumigation } \\
\text { CL }_{50}(\text { CI 95\%) }\end{array}$ & $\chi^{2}$ & $\mathrm{TR}_{50}(\mathrm{CI} 95 \%)$ \\
\hline \multirow{2}{*}{ O. duckei } & Fumigation & 540 & 4 & $\begin{array}{c}2.09 \\
(1.94-2.23)\end{array}$ & $0.52(0.40-0.67)$ & 5.87 & $148.78(74.78-196.92)$ \\
\hline & Contact & 175 & 5 & $\begin{array}{c}1.89 \\
(1.64-2.11)\end{array}$ & $4.68(3.50-6.20)$ & 4.54 & $1.17 \times 10^{4}\left(1.01 \times 10^{4}-1.31 \times 10^{4}\right)$ \\
\hline \multirow{2}{*}{ O. glomerata } & Fumigation & 540 & 4 & $\begin{array}{c}3.10 \\
(2.86-3.34)\end{array}$ & $1.32(1.00-1.61)$ & 8.68 & $374.76(290.76-447.36)$ \\
\hline & Contact & 150 & 4 & $\begin{array}{c}2.99 \\
(2.61-3.37)\end{array}$ & $7.22(5.89-8.76)$ & 1.96 & $2.4 \times 10^{4}\left(2.23 \times 10^{4}-2.65 \times 10^{4}\right)$ \\
\hline \multirow{2}{*}{ FMD } & Fumigation & 630 & 5 & $\begin{array}{c}3.28 \\
(3.06-3.50)\end{array}$ & $0.78(0.66-0.86)$ & 1.81 & $192.70(164.71-234.12)$ \\
\hline & Contact & 150 & 4 & $\begin{array}{c}3.06 \\
(2.66-3.46)\end{array}$ & $5.02(3.86-7.12)$ & 3.55 & $1.25 \times 10^{4}\left(1.10 \times 10^{4}-1.41 \times 10^{4}\right)$ \\
\hline \multirow{2}{*}{ FMG } & Fumigation & 540 & 4 & $\begin{array}{c}4.98 \\
(4.58-5.37)\end{array}$ & $2.47(2.11-2.69)$ & 8.89 & $616.08(587.54-666.91)$ \\
\hline & Contact & 150 & 4 & $\begin{array}{c}6.21 \\
(5.40-7.01)\end{array}$ & $23.99(21.76-26.34)$ & 1.81 & $6.00 \times 10^{6}\left(5.71 \times 10^{6}-6.35 \times 10^{6}\right)$ \\
\hline $\mathrm{EU}$ & Fumigation & 580 & 5 & $\begin{array}{c}0.84 \\
(0.72-0.97)\end{array}$ & $\begin{array}{c}4.0 \times 10^{-3} \\
\left(2.0 \times 10^{-4}-8.0 \times 10^{-4}\right)\end{array}$ & 2.50 & - \\
\hline Azamax & Contact & 540 & 4 & $\begin{array}{c}2.45 \\
(2.25-2.64) \\
\end{array}$ & $\begin{array}{c}3.0 \times 10^{-4} \\
\left(2.4 \times 10^{-4}-4.0 \times 10^{-4}\right)\end{array}$ & 8.04 & - \\
\hline
\end{tabular}

$\mathrm{FMD}=$ Full mixture of selected constituents in the oil from $O$. duckei; FMG = Full mixture of selected constituents in the oil from $O$. glomerata (prepared at same percentage composition identified by GC/MS analyses of $O$. duckei and $O$. glomerata); Eugenol (EU) and Azamax used as positive control; $\mathrm{n}=$ number of mites/dose; $\mathrm{df}=$ degrees of freedom; $\mathrm{LC}_{50}=\mathrm{Median}_{\mathrm{Lethal}}$ Concentration; $\mathrm{CI}=$ confidence interval; $\chi^{2}=$ chi-squared; $\mathrm{TR}=$ toxicity ratio.

differences in the chemical constituents identified in the oils. Toxicity of the major constituents selected from the two oils also varied in accordance with the method employed (fumigation and residual contact).

To identify variations in the toxicity of the selected constituents determined during the fumigation bioassays, these compounds were divided into six groups from the most toxic to the least toxic based on the intensity of the acaricidal action: Group A - $\beta$-caryophyllene; Group B - terpinen-4-ol; Group C - terpinolene and $\alpha$-humulene; Group D - $\alpha$-humulene, $\alpha$-terpineol and $p$-cymene; Group E - $p$-cymene, $\beta$-pinene, valencene and aromadendrene; and Group F aromadendrene, limonene and $\alpha$-pinene. The same procedure was used for the relative toxicity of the compounds tested using the residual contact method, for which five groups were determined: Group A - $\beta$-caryophyllene; Group B - $\alpha$-humulene, $\alpha$-pinene, $p$-cymene, $\alpha$-terpineol, aromadendrene and valencene; Group C - $\beta$-pinene, $\alpha$-pinene, $p$-cymene, $\alpha$-terpineol, aromadendrene and valencene; Group D - limonene; and Group E terpinolene and terpinen-4-ol. The findings suggest that $\beta$-caryophyllene was the most toxic constituent, independently of the method employed. Terpinen4-ol was the second most toxic in the fumigation bioassays, whereas terpinen-4-ol and terpinolene exhibited the least toxicity in the residual contact bioassays.

In the fumigation bioassays, $\beta$-caryophyllene proved to be 13-fold and 33-fold more toxic than the $O$. duckei and $O$. glomerata oils, respectively. In the residual contact bioassays, this sesquiterpene was seven-fold and 11-fold more toxic than the 
$O$. duckei and O. glomerata oils, respectively. Other constituents of the $O$. glomerata oil also demonstrated significant toxicity, such as terpinen-4-ol, which was three-fold more toxic than the oil. The acaricidal activity of the Ocotea oils may therefore be attributed to the chemical constituents with greater toxicity. These data also suggest a possible antagonistic interaction of some constituents of the Ocotea oils against $\beta$-caryophyllene.

The high susceptibility of mites exposed to the Ocotea oils and individual compounds using the fumigation method has been reported for other essential oils and their chemical constituents (Moraes et al. 2012, Neves and da Camara 2016). This demonstrates that such products are more toxic to T. urticae through the penetration of vapors in the respiratory system (fumigation) than ingestion and/ or penetration through the tarsi (residual contact).

TOXICITY OF ARTIFICIAL OILS: BLENDS OF CONSTITUENTS SELECTED FROM Ocotea OILS

Table III displays the mean lethal concentrations during the fumigation and residual contact bioassays of the chemical constituents (artificial oils) selected from the Ocotea oils at the same proportion in which these compounds were identified by GC-MS. Toxicity of the artificial oil from $O$. duckei was the same as that found for the essential oil. However, the artificial oil prepared from seven constituents of the $O$. glomerata oil was 1.8-fold and 3.3-fold less toxic than the essential oil in the fumigation and residual contact bioassays, respectively. The results suggest that the absence of non-selected constituents did not directly affect the toxicity of the artificial oil derived from $O$. duckei, whereas non-selected constituents were important to the toxicity of the artificial oil derived from O. glomerata. Neither of the artificial oils prepared from the constituents of the Ocotea oils were more active than eugenol and azamax used as the positive control in the fumigation and residual contact bioassays, respectively.

ATTRIBUTION OF ROLE OF TERPENES IN TOXICITY OF ARTIFICIAL OILS DERIVED FROM $O$. duckei AND O. glomerata

Figure 1 shows the mean mite mortality values for the blends prepared with the absence of one of the constituents of the artificial oil derived from $O$. duckei (incomplete blend).

In the fumigation bioassays, the removal of the minor constituents $\alpha$-pinene $(2.5 \pm 0.1 \%)$, $\beta$-pinene $(5.2 \pm 0.0 \%), \alpha$-terpinenol $(0.3 \pm 0.0 \%)$, aromadendrene $(0.5 \pm 0.0 \%)$ or $\alpha$-humulene $(2.2 \pm$ $0.0 \%$ ) did not affect the toxicity of the artificial oil and the removal of limonene $(1.1 \pm 0.0 \%)$ exerted a small effect. In contrast, when one of the main constituents $[\beta$-caryophyllene $(18.1 \pm 0.1 \%)$ or valencene $(17.6 \pm 0.0 \%)]$ was removed, the toxicity of the incomplete blend was drastically reduced. These findings suggest that $\beta$-caryophyllene and valencene contribute most to the toxicity of the artificial oil using the fumigation method. In the residual contact tests involving the incomplete blends, the major constituents $\beta$-caryophyllene and valencene as well as the minor constituent $a$-humulene contributed most to the toxicity of the artificial oil derived from $O$. duckei. The findings indicate that $\beta$-caryophyllene, which is the main component of the oil and most toxic individually, is the compound that contributes most to the toxicity of the artificial oil using the fumigation and residual contact methods. These results are in agreement with data reported by Miresmailli et al. (2006), who demonstrated the role of the major constituents $(1,8$-cineole and $\alpha$-pinene $)$ in the toxicity of the oil from Rosmarinus officinalis against Tetranychus urticae. However, the results are in disagreement with data described by Neves and da Camara (2016) for 1,8-cineole, which is the main constituent of an artificial oil derived from the leaves of Vitex agnus-castus. 


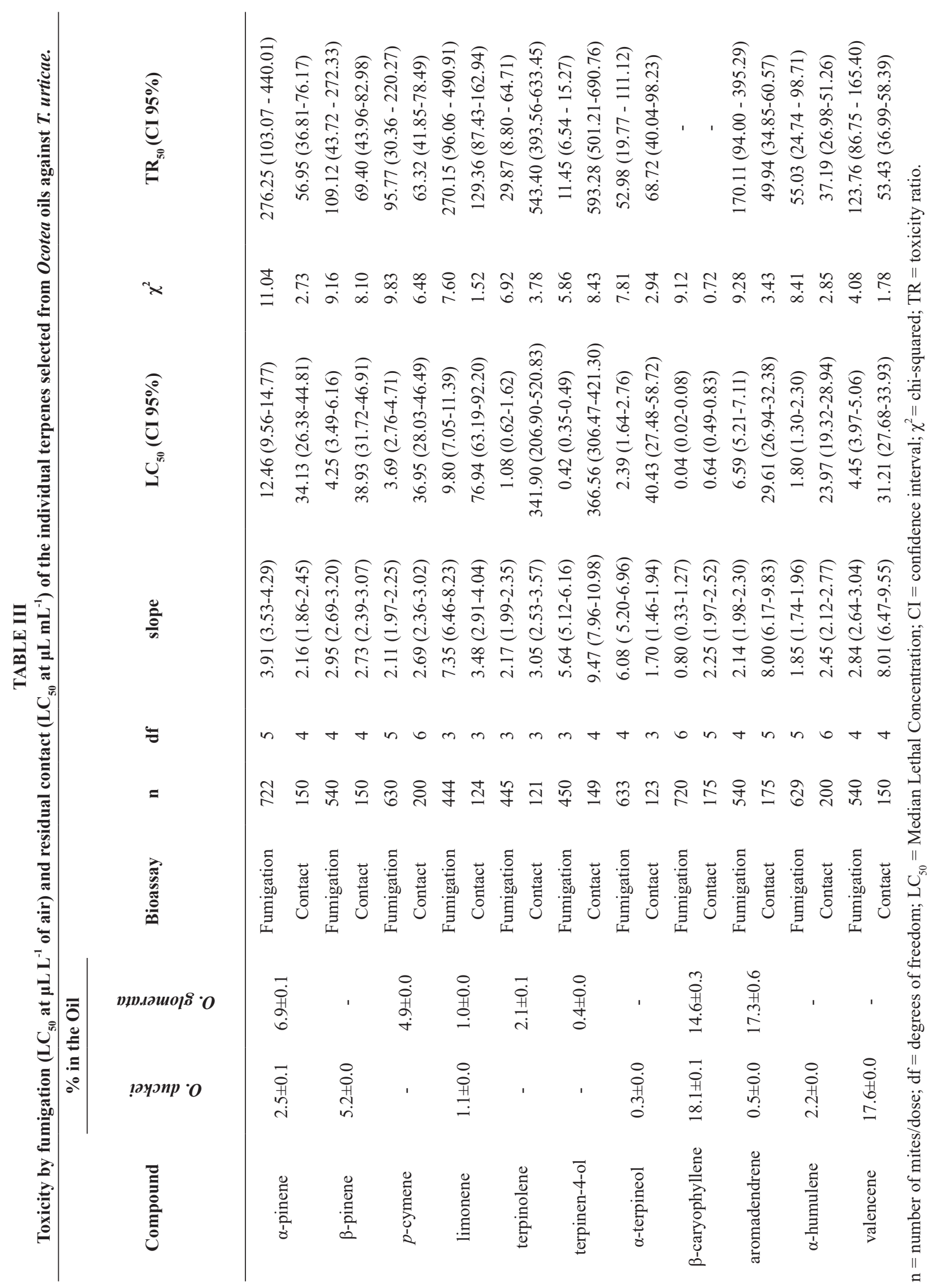




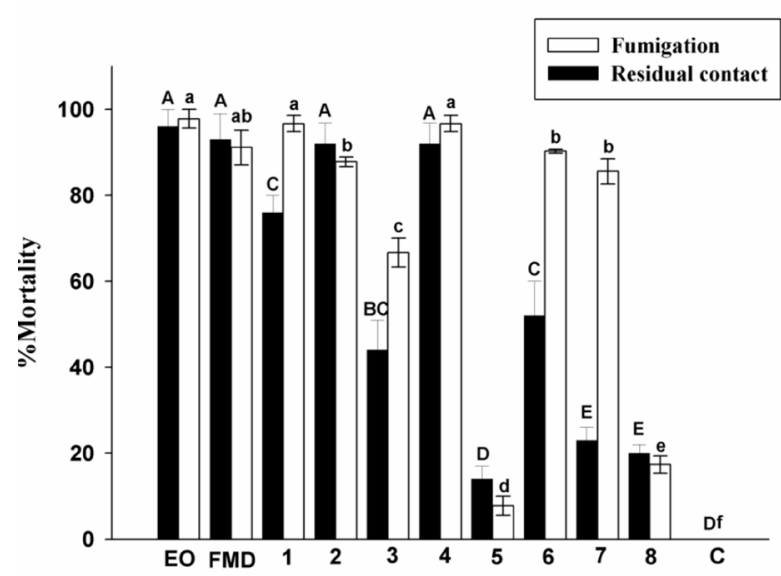

Figure 1 - Mean mortality caused by incomplete blends prepared with the removal of one constituent from the complete artificial blend of $O$. duckei at concentration equivalent to the experiment with the leaf oil that promoted $\geq 96.0 \%$ mortality (3.2 $\mu \mathrm{L} \mathrm{L} \mathrm{L}^{-1}$ air for fumigation and $20 \mu \mathrm{L} \mathrm{mL}^{-1}$ for residual contact). Bars with the same uppercase or lowercase not differ significantly by Tukey test $(\mathrm{P} \leq 0.05)$. EO = essential oil from O. duckei, FMD = Full mixture of selected constituents in the oil from $O$. duckei. The numbers indicate the blends with the absence of the labeled compound. $1=\alpha$-pinene; $2=\beta$-pinene; 3 = limonene; $4=\alpha$-terpineol; $5=\beta$-caryophyllene; $6=$ aromadendrene; $7=\alpha$-humulene; $8=$ valencene; $\mathrm{C}=$ control.

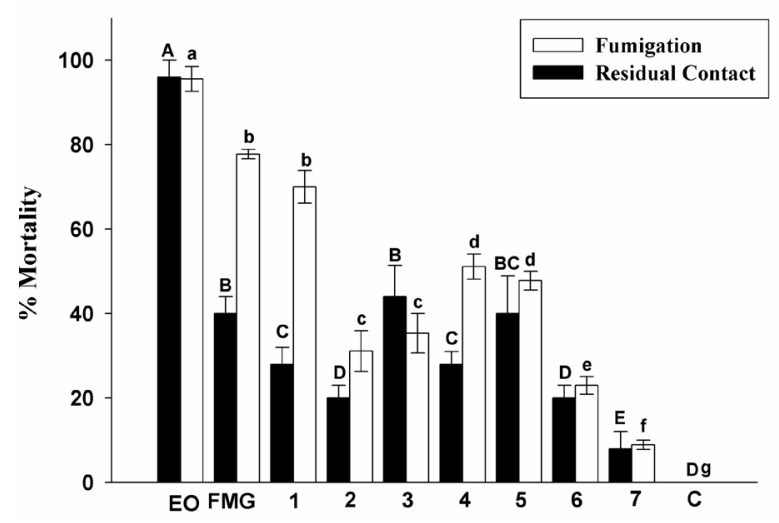

Figure 2 - Mean mortality of mite caused by incomplete blends prepared with the removal of one constituent from the complete artificial blend of the leaf oil of $O$. glomerata at concentration equivalent to the experiment with the leaf oil that promoted mortality $\geq 96.0 \%\left(3.6 \mu \mathrm{L} \mathrm{L}^{-1}\right.$ air for fumigation and $22 \mu \mathrm{L} \mathrm{mL}^{-1}$ to residual contact). Bars with the same uppercase or lowercase not differ significantly by Tukey test $(\mathrm{P} \leq 0.05) . \mathrm{EO}=$ essential oil from $O$. glomerata, $\mathrm{FMG}=$ Full mixture of selected constituents in the oil from O. glomerata. The numbers indicate the blends with the absence of the labeled compound. $1=\alpha$-pinene; $2=p$-cymene; 3 = limonene; $4=\alpha$-terpinolene; $5=$ terpinen-4-ol; $6=\beta$-caryophyllene; $7=$ aromedendrene; $\mathrm{C}=$ control.
Figure 2 displays the relative toxicities of the incomplete blends of the artificial oil derived from O. glomerata.

The removal of $\alpha$-pinene $(6.9 \pm 0.1 \%)$ did not affect the toxicity of the artificial oil in the fumigation bioassay and the toxicity of the artificial oil was not reduced by the removal of limonene $(1.0 \pm 0.0 \%)$ or terpinen- 4 -ol $(0.4 \pm 0.0 \%)$ in the residual contact bioassay. In contrast, the removal of aromadendrene $(17.3 \pm 0.6 \%)$ led to a drastic reduction in mite mortality, indicating that this sesquiterpene contributed most to the toxicity of the artificial oil from $O$. glomerata, followed by $\beta$-caryophyllene $(14.6 \pm 0.3 \%)$ and $p$-cymene $(4.9 \pm$ $0.0 \%$ ). Comparing the individual relative toxicities of the constituents that most contributed to the toxicity of the artificial oil from $O$. glomerata, the major component, aromadendrene, exhibited the same degree of toxicity as $p$-cymene, independently of the method employed (fumigation or residual contact), whereas the second major component of the artificial oil, $\beta$-caryophyllene, was 170 fold and 50-fold more toxic than aromadendrene in the fumigation and residual contact bioassays, respectively. These results suggest that the contribution of one chemical constituent in a complex blend is not predictable based solely on its individual toxicity or the proportion at which it is found in the blend.

\section{CONCLUSIONS}

This study confirmed the terpene nature with a predominance of sesquiterpenes in essential oils from species of the genus Ocotea. Although the oils investigated have the same chemical profile, the present study enabled the determination of qualitative and quantitative differences in the chemical composition of the oils from $O$. duckei and $O$. glomerata. The chemotype $\beta$-caryophyllene found in the oil from $O$. duckei occurring in a fragment of the Atlantic Forest in the state of 
Pernambuco in northeastern Brazil is the same as that found in the oil from $O$. duckei collected from a fragment of the Atlantic Forest in the state of Paraíba in the same region of the country.

The two-spotted spider mite was more susceptible to the oil from $O$. duckei than that from $O$. glomerata, independently of the method employed. Both oils were more toxic when using the fumigation method, which suggests better action of the oils through the penetration of the airways of the mite than through ingestion or contact with the tarsi.

The bioassays with the selected constituents and different blends prepared with these compounds demonstrated that the contribution of a single chemical constituent to the toxicity of the complete blend is not predictable based solely on individual toxicity or the proportion at which the compound is found in the blend. Therefore, possible interactions among these constituents should be taken into consideration.

\section{ACKNOWLEDGMENTS}

The authors are grateful to the Conselho Nacional de Desenvolvimento Científico e Tecnológico (CNPq) and Coordenação de Aperfeiçoamento de Pessoal de Nível Superior (CAPES) for awarding a grant (CAPES - Proc. N IBPG-0984-5.01/10; scholarship of productivity CNPq, No $312277 / 2013-$ $0)$ and funding this study (CNPq No 477778/2013-5).

\section{REFERENCES}

ADAMS RP. 2007. Identification of Essential Oil Components by Gas Chromatography/Quadrupole Mass Spectroscopy, $4^{\text {th }}$ ed., Allured Publishing Corporation: Carol Stream, $804 \mathrm{p}$.

ARAÚJO MJC, DA CAMARA CAG, BORN FS, MORAES MM AND BADJI CA. 2012. Acaricidal activity and repellency of essential oil from Piper aduncum and its components against Tetranychus urticae. Exp Appl Acarol 57: $139-155$.

BAITELLO JB. 2001. Novas espécies de Lauraceae para a flora brasileira. Acta Bot Bras 15: 445-450.

BALLABENI V, TOGNOLINI M, BERTONI S, BRUNI R, GUERRINI A, RUEDA GM AND BAROCELLI E. 2007. Antiplatelet and antithrombotic activities of essential oil from wild Ocotea quixos (Lam.) Kosterm. (Lauraceae) calices from Amazonian Ecuador. Pharmacol Res 55: 2330 .

BARBOSA-FILHO JM, CUNHA RM, DIAS CS, ATHAYDE PF, SILVA MS, DA CUNHA EV, MACHADO MIL, CRAVEIRO AA AND MEDEIROS IA. 2007. GC-MS Analysis and cardiovascular activity of the essential oil of Ocotea duckei. Rev Bras Farmacogn 18: 37-41.

BARRETO RC. 1990. O gênero Ocotea Aubl. (Lauraceae) no Estado de Pernambuco. Anais do $36^{\circ}$ Congresso Nacional de Botânica 1: 175-199.

CHAVERRI C AND CICCIÓ JF. 2007. Essential oils from Ocotea austinii C. K. Allen (Lauraceae) from Costa Rica. J Essent Oil Res 19: 439-443.

CHAVERRI C, DIAZ C AND CICCIÓ JF. 2011. Chemical analysis of essential oils from Ocotea gomezii WC Burger and Ocotea morae Gomez-Laur. (Lauraceae) collected at "Reserva Biologica Alberto M. Brenes" in Costa Rica and their cytotoxic activity on tumor cell lines. J Brazil Chem Soc 22: 741-745.

COUTINHO DF, AGRA MF, BARBOSA-FILHO JM AND BASÍLIO IJLD. 2006. Morfo-anatomia foliar de Ocotea gardneri (Meisn.) Mez (Lauraceae-Lauroideae). Rev Bras Farmacogn 16: 178-184.

COUTINHO DF, DIAS CS, BARBOSA-FILHO JM, AGRA MF, MARTINS RM, SILVA TMS, DA CUNHA EVL, SILVA MS AND CRAVEIRO AA. 2007. Composition and molluscicidal activity of the essential oil from the stem bark of Ocotea bractelosa (Meisn.) mez. J Essent Oil Res 19: 482-484.

DA CAMARA CAG, AKHTAR Y, ISMAN MB, SEFFRIN RC AND BORN FS. 2015. Repellent activity of essential oils from two species of Citrus against Tetranychus urticae in the laboratory and greenhouse. Crop Prot 74: 110-115.

DESTRYANA RA, YOUNG DG, WOOLLEY CL, HUANG TC, WU HY AND SHIH WL. 2014. Antioxidant and anti-inflammation activities of Ocotea, Copaiba and blue cypress essential oils in vitro and in vivo. J Am Oil Chem Soc 91: 1531-1542.

FARAGO PV, DE PAULA JFP, NAKASHIMA T, DÖLLBOSCARDIN PM, BUDEL JM AND MAIA BHLNS. 2010. Chemical composition and antibacterial activity of the essential oil from bark of Ocotea puberula (Rich.) Ness. Lat Am J Pharm 29: 1242-1245.

GARRETT R, CRUZ RAS, ROCHA L, SANTOS MG AND DA SILVA AJR. 2010. Chemical composition and toxicity of Ocotea notata (Nees) Mez Essential Oil. J Essent Oil Bear P1 13: 445-459.

IBAMA - INSTITUTO BRASILEIRO DO MEIO AMBIENTE E DOS RECURSOS NATURAIS RENOVÁVEIS. 1992. Portaria n. 37-N, 3 de abril 1992. Lista oficial de flora brasileira ameaçada de extinção. http://www.mma.gov. 
br/estruturas/179/ arquivos/179 05122008033627.pdf. Acessado em novembro de 2016.

ISMAN MB AND MIRESMAILLI S. 2011. Plant essential oils as repellents and deterrents to agricultural pests. In: Paluch GE and Coats JR (Eds), Recent developments in invertebrate repellents, ACS Symposium Series, USA, 1090, p. 67-77.

ISMAN MB, MIRESMAILLI S AND MACHIAL C. 2011. Commercial opportunities for pesticides based on plant essential oils in agriculture, industry and consumer products. Phytochem Rev 10: 197-204.

JIANG Z, AKHTAR Y, BRADBURY R, ZHANG X AND ISMAN MB. 2009. Comparative toxicity of essential oils of Litsea pungens and Litsea cubeba and blends of their major constituents against the Cabbage Looper, Trichoplusia ni. J Agric Food Chem 57: 4833-4837.

LEORA S. 1987. POLO-PC: A User's Guide to Probit Logit Analysis; Berkely.

LEPORATTI ML, PINTORE G, FODDAI M, CHESSA M, PIANA A, PATRETTO GL, MASIA MD AND NICOLETTI M. 2014. Chemical, biological, morphoanatomical and antimicrobial study of Ocotea puchury-major Mart. Nat Prod Res 28: 294-300.

MENUT C, BESSIERE JM, HASSANI MS, BUCHBAUER G AND SCHOPPER B. 2002. Chemical and biological studies of Ocotea comoriensis bark essential oil. Flavour Fragr J 17: 459-461.

MIRESMAILLI S, BRADBURY R AND ISMAN MB. 2006. Comparative toxicity of Rosmarinus officinalis L. essential oil and blends of its major constituents against Tetranychus urticae Koch (Acari : Tetranychidae) on two different host plants. Pest Manag Sci 62: 366-371.

MORAES MM, DA CAMARA CAG, DOS SANTOS ML AND FAGG CW. 2012. Essential Oil Composition of Eugenia langsdorffii O. Berg.: Relationships between some terpenoids and toxicity against Tetranychus urticae. J Brazil Chem Soc 23: 1647-1656.

MORAES PLR. 2005. Sinopse das Lauráceas nos estados de Goiás e Tocantins, Brasil Biota Neotrop 5: 1-18.

MORAIS L, BARBOSA JM AND ALMEIDA RN. 1998. Central depressant effects of reticuline extracted from Ocotea duckei in rats and mice. J Ethnopharmacol 62: 5761.

MOSSI AJ, ZANELLA CA, KUBIAK G, LERIN LA, CANSIAN RL, FRANDOLOSO SF, PRÁ VD, MAZUTTI MA, COSTA JAV AND TREICHEL H. 2013. Essential oil of Ocotea odorifera: An alternative against Sitophilus zeamais. Renew Agr Food Syst 29: 161-166.

NASCIMENTO AF, DA CAMARA CAG, DE MORAES MM AND RAMOS CS. 2012. Essential oil composition and acaricidal activity of Schinus terebinthifolius from Atlantic Forest of Pernambuco, Brazil against Tetranychus urticae. Nat Prod Commun 7: 129-132.
NEVES IA AND DA CAMARA CAG. 2011. Acaricidal Activity against Tetranychus urticae and essential oil composition of four Croton species from caatinga biome in Northeastern Brazil. Nat Prod Commun 6: 893-899.

NEVES RCS AND DA CAMARA CAG. 2016. Chemical composition and acaricidal activity of the essential oils from Vitex agnus-castus L. (Verbenaceae) and selected monoterpenes. An Acad Bras Cienc 88: 1221-1233.

OLIVERO-VERBEL J, CERVERA GT, FERNANDEZ GJ, COLORADO JB AND STASHENKO E. 2010. Chemical composition and antioxidant activity of essential oils isolated from Colombian plants. Rev Bras Farmacogn 20: 568-574.

OLTRAMARI AC, WOOD KV, BONHAM C, VERPOORTE R, CARO MSB, VIANA AM, PEDROTTI EL, MARASCHIN RP AND MARASCHIN M. 2004. Safrole analysis by GC-MS of prototrophic (Ocotea odorifera (Vell.) Rohwer) cell cultures. PCTOC 78: 231-235.

QUINET A, BAITELLO JB AND MORAES PLR. 2010. Lauraceae. In: Forzza RC et al. (Eds), Lista de espécies da flora do Brasil. Jardim Botânico do Rio de Janeiro. Rio de Janeiro, RJ, p. 1167-1158.

RIBEIRO NC, DA CAMARA CAG AND RAMOS CS. 2016. Toxicity of essential oils of Piper marginatum Jacq. against Tetranychus urticae Koch and Neoseiulus californicus (McGregor). Chil J Agr Res 76: 71-76.

ROBERTSON JL AND PREISLER HK. 1992. Pesticide Bioassays with Arthropods. FL: CRC Boca Raton, 127 p.

SACCHETTI G, GUERRINI A, NORIEGA P, BIANCHI A AND BRUNI R. 2006. Essential oil of wild Ocotea quixos (Lam.) Kosterm. (Lauraceae) leaves from Amazonian Ecuador. Flavour Frag J 21: 674-676.

SAS INSTITUTE. 2002. SAS/User's Guide: Statistics, version 9.0, $7^{\text {th }}$ ed., SAS Institute Inc.: Cary.

SETZER WN, TAKAKU S, STOKES SL AND PENTON AF. 2006. Inhibition of cruzain by Ocotea leaf essential oils from Monteverde, Costa Rica. PhOL 3: 785-793.

TAKAKU S, HABER WA AND SETZER WN. 2007. Leaf essential oil composition of 10 species of Ocotea (Lauraceae) from Monteverde, Costa Rica. Biochem Syst Ecol 35: 525-532.

VAN DEN DOOL H AND KRATZ PD. 1963. A generalization of the retention index system including linear temperature programmed gas liquid partition chromatography. J Chromatogr A 11: 463-471.

VAN DER WERFF H. 1991. A key to the genera of Lauraceae in the new world. Annals of the Missouri Botanical Garden 78: 377-387.

YAMAGUCHI KKL, ALCANTARA JM, LIMA ES AND VEIGA-JUNIOR VF. 2013. Chemical composition and platelet aggregation activity of essential oils of two species of the genus Ocotea (Lauraceae). J Essent Oil Bear P1 16: 518-523. 